\title{
Ozone application for tofu waste water treatment and its utilisation for medium growth of microalgae Spirulina $s p$
}

\author{
Hadiyanto Hadiyanto ${ }^{1,2}$ \\ ${ }^{1}$ Chemical Engineering Department, Faculty of Engineering, Diponegoro University, Indonesia \\ ${ }^{2}$ Master Program of Environnemental Sciences, School of Postgraduate Studies, Diponegoro University, Indonesia
}

\begin{abstract}
Tofu industries produce waste water containing high organic contents and suspendid solid which is harmful if directly discharged to the environment. This waste can lead to disruption of water quality and lowering the environmental carrying capacity of waters around the tofu industries. Besides, the tofu waste water still contains high nitrogen contents which can be used for microalgae growth. This study was aimed to reduce the pollution load (chemical oxygen demand-COD) of tofue wastewater by using ozone treatments and to utilize nutrients in treated tofu waste water as medium growth of microalgae. The result showed that the reduction of COD by implementation of ozone treatment followed first order kinetic. Under variation of waste concentrations between $10-40 \%$, the degradation rate constant was in the range of $0.00237-0.0149 \mathrm{~min}^{-1}$. The microalgae was able to grow in the tofue waste medium by the growth rate constants of $0.15-0.29$ day $^{-1}$. This study concluded that tofu waste was highly potent for microalgae growth.
\end{abstract}

\section{Introduction}

Tofu is local food in Indoensia, and its consumption reaches $7.4 \mathrm{~kg} /$ person / year [1]. The production process of tofu produces liquid waste in a large quantity with the average amount of 17 Litres per $\mathrm{kg}$ of processed soybeans[2]. The waste still contains organic content such as protein and lipids of about $40-60 \%$ and carbohydrates about $25-50 \%$ [1]. Besides, tofu waste water still contains total nitrogen contents of $188.34 \mathrm{mg} / \mathrm{L}$, and total phosphorus of $1.69 \mathrm{mg} / \mathrm{L}$. These nutrient contents can be a potent as a nutrient for microalgae [3].

Microalgae is microorganism that capable to use nutrient of nitrogen and phosphorous for photosynthesis to produce biomass and oxygen[4]. The nitrogen is required for the formation of protein, the cell walls, and nucleic acid. Microalgae also requires a source of carbon and sunlight as energy sources.

On the other hand, the tofu waste has a very high COD content of $8640 \mathrm{ppm}$ and BOD content of 6586 ppm[3]. High levels of COD/BOD will interfere the growth of microalgae, therefore a pre-treatment is required to reduce $\mathrm{COD} / \mathrm{BOD}$ level in the waste. There are many kind of pretreatment for wastewater treatments such as physical, biological and chemical treatments. These methods require longer processing time. Oxidation using ozone is one methods to reduce the COD level in the waste. Ozone is a very strong oxidizing agent $(\mathrm{E}=2.08 \mathrm{~V})$ compared to other oxidizing agents such as hydrogen peroxide $(\mathrm{E}=1.78 \mathrm{~V})$ [5]. Ozone has been extensively used in industrial processes to eliminate the presence of pollutants in wastewater. Ozone is also able to decompose organic components into simpler and more biodegradable compounds. Moreover, ozone is also commonly used as a disinfectant in drinking water, preserving food and reducing odor from bacteria in waste.

The efficiency of ozone higly depends on $\mathrm{pH}$ as an indication of hydrogen ion activity. A high $\mathrm{pH}$ will facilitate the formation of $\mathrm{OH}$ radicals because the presence of $\mathrm{OH}$ ions can initiate ozone decomposition as a first step in the production of $\mathrm{OH}$ radicals [6], whereas at low $\mathrm{pH}$ the ozone molecule remains as its initial oxidant.

The objective of this study was evaluate the use of ozone for oxidation of tofu waste such that COD will be degraded. The treated waste will be also used medium growth of microalgae Spirulina $s p$.

\section{Material and Methods}

\section{Material}

Tofu wastewater was obtained from local indsutry in Gunung Pati, Semarang. The microalgae Spirulina was prodived by CV Neoalgae.

\section{Sample Preparation and Ozone Treatment}

The tofu waste was varied in the range of $10-40 \%(\mathrm{v} / \mathrm{v})$ in $1 \mathrm{~L}$ erlenmeyer. The sample was placed in the container and 
continously imposed by ozone. The sample was taken every 10 min to measure its COD concentration.

\section{Cultivation of Microalgae}

The treated waste was then used as medium growth of microalgae. The control used fresh water with external nutrients of $0.05 \mathrm{gr}$ of urea fertilizer, $1.5 \mathrm{gr}$ of fine salt, 0.1 ppm vitamin B12, and $0.05 \mathrm{~g}$ of NPK fertilizer. The sample was measured for its opticald ensity at $620 \mathrm{~nm}$. Cultivation was carried out for 7 days and the concentration was monitored by daily measuring its optical density .

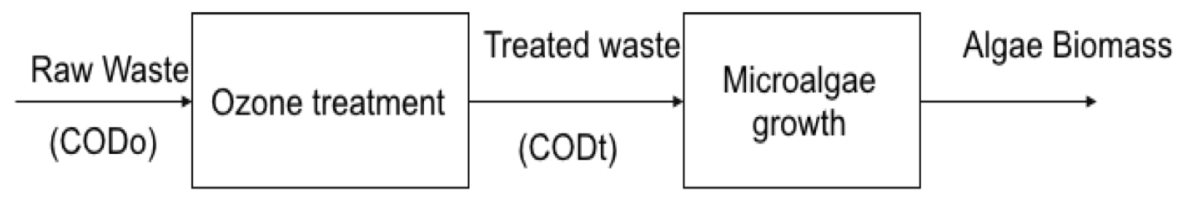

Figure 1. Research step of tofu treatment and utilization of its nutrient for microalgae growth

\section{Cell Number Analysis}

Take $5 \mathrm{ml}$ of microalgae sample and diluted up to 10 dilutions. Take $1 \mathrm{ml}$ of diluted sample and inserted it into the Sedgwick-Rafter plate. Count the number of cells with a 10x10 magnification microscope with a calculated $7 \times 7$ plate area.

\section{Result and Discussion}

\section{Effect of Waste Concentration on COD Degradation}

The research was conducted on 4 variations of waste concentration, i.e. $10 \%, 20 \%, 30 \%$ and $40 \%$ of tofu waste. The COD sample values were analyzed every 15 minutes, during the 2 hour ozone treatment. The effect of the concentration of tofu waste on the decrease of COD concentration is depicted in Figure 2. Figure 2 shows that the degradation of COD at high waste concentration $(>40 \%)$ goes in slow decrease. It might due to high amount of total solids in waste which difficult to oxidize by ozone treatment. The degradation rate was determined by fitting the first order reation kinetic to the experimental data. The result is shown by Table 1 .

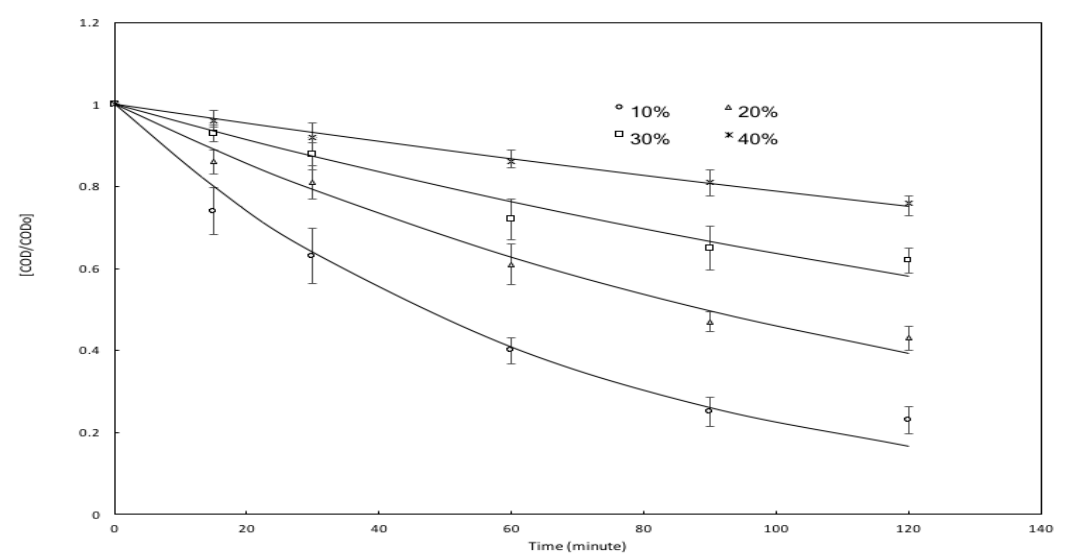

Figure 2. First-order kinetics of the ozone decomposition

Table 1. First-order kinetics of the ozone decomposition of waste water

\begin{tabular}{lc}
\hline Concentration & Kinetic rate constant $\left(\mathbf{m i n}^{-1}\right)$ \\
\hline $10 \%$ & 0.0149 \\
$20 \%$ & 0.00779 \\
$30 \%$ & 0.00453 \\
$40 \%$ & 0.00237 \\
\hline
\end{tabular}


Table 1 also proves that ozone is a powerful oxidizing agent capable of oxidizing various compounds. Ozone oxidizes compounds in water in two ways: direct reaction and indirect reactions [7]. For direct method, the oxidation is carried out by ozone itself that dissolved in water. While indirect method, the oxidation occurs by producing $\mathrm{OH}$ radicals that would oxidize other compounds [6]. The longer the ozonation time, the more ozone will be formed that will oxidize the compound, resulting in lower COD values due to the simpler compounds.

The utilization of nutrient for microalgae growth Spirulina platensis requires nutrients $\mathrm{C}, \mathrm{H}, \mathrm{O}, \mathrm{N}$ and $\mathrm{P}$ in their growth to perform photosystasis. The growth of microalgae in treated waste at $10 \%$ waste concentration has higher growth rate constant than $20-40 \%$. Moreover, this finding also support the hypothesis that the nutrients in the waste water can be used to replaced the external nnutrients added to the medium. Although the growth of microalgae grown in waste medium was lower than the control (Figure 3 ), but this findings showed that the waste has high potent to replace the external nutrients. The growth rate constant is shown by Table 2 . The growth rate constant at high waste consentration is slower than algae growth in lower concentration. This is due to high organic content whcih will disturb the growth and inhibit the light penetration to the culture.

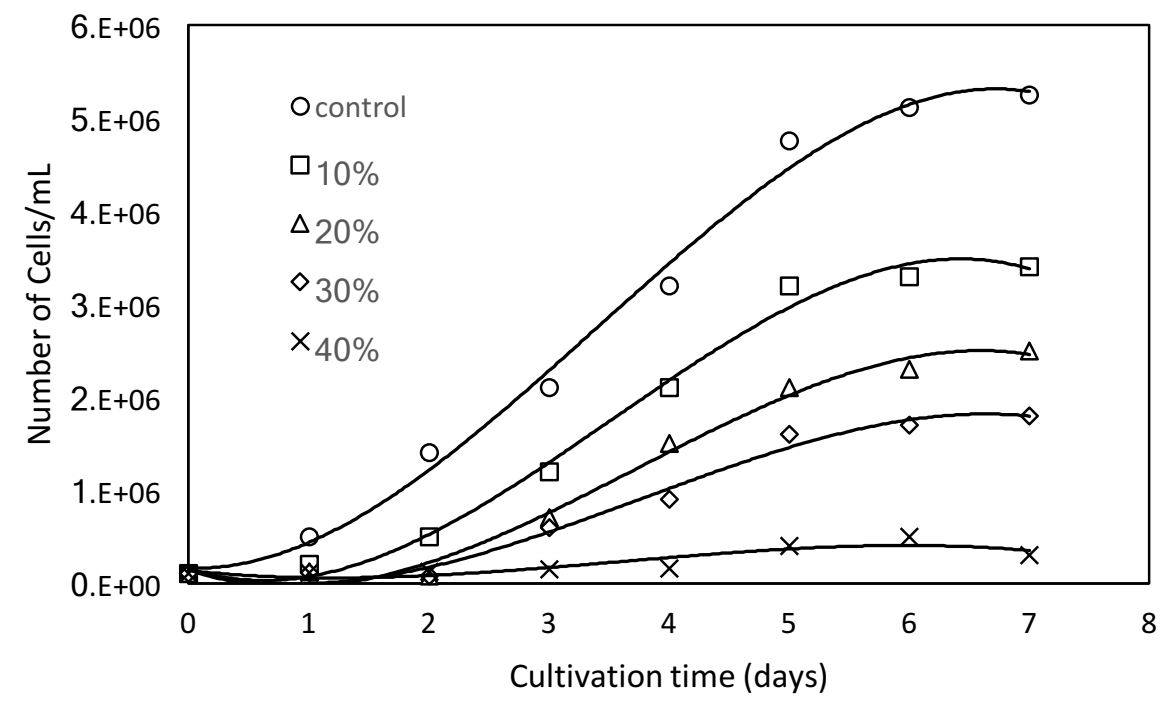

Figure 3. Growth of microalgae in variation of tofu waste volume

Table 2. Growth rate of Spirulina platensis in cultivation medium

\begin{tabular}{cc}
\hline $\begin{array}{c}\text { Medium } \\
\text { (\% tofu wastewater) }\end{array}$ & $\boldsymbol{\mu} / \mathbf{d a y}$ \\
\hline $10 \%$ & 0.2848 \\
$20 \%$ & 0.2339 \\
$30 \%$ & 0.2103 \\
$40 \%$ & 0.1497 \\
\hline
\end{tabular}

\section{Conclusion}

This study showed the potency of tofu waste water as nutrient source of microalgae growth. The degradation of COD by using ozone oxidator followed the first orde kinetic with rate constant of 0.014 for $10 \%$ tofu concentration. The treated tofu waste could be used as nutrient source of Spirulina growth with growth rate of 0.28 day $^{-1}$ at $10 \%$ concentration. However, at concentration higher than $40 \%$, the microalgae has lower growth rate.

\section{References}

1. Dianursanti, Rizkyata, B.T., Gumelar, M.T. and Abdullah, T.H. Energy Procedia, 47, 56 - 61 (2014) 
2. Hadiyanto and Nur, M.M.A. World Applied Sciences Journal, 31(5),959-967 (2014) .

3. Hadiyanto, Christwardana, M., Soetrisnanto, D. Journal of Environmental Science and Technology 6(2), 79-90 (2013)

4. Wen, Z., Gross, M., Ninno, M. D., \& Michael, C. Bioresource Technology, 179, 473-482 (2015).
5. Rajeswari, R., Kanmani, S. Desalination, 242, 277e285 (2009).

6. Nur, M.M.A and Hadiyanto. Journal of Engineering and Technological Sciences 47(5), 487-497 (2015).

7. Balasubramaniam N., Preethi V., Parama Kalyani, K.S., Iyappan, K., Srinivaskannan, C. Journal of Hazardous Materials, 166, 150-154 (2009). 